\title{
Frost damage in Pinus sylvestris L. stems assessed by chlorophyll fluorescence in cortical bark chlorenchyma
}

\author{
José Javier Peguero-PinA ${ }^{1}$, Fermín Morales ${ }^{2}$, Eustaquio GIL-PELEGRín ${ }^{1 *}$ \\ ${ }^{1}$ Unidad de Recursos Forestales, Centro de Investigación y Tecnología Agroalimentaria, Gobierno de Aragón, Apdo. 727, 50080 Zaragoza, Spain \\ ${ }^{2}$ Department of Plant Nutrition, Experimental Station of Aula Dei, CSIC, Apdo. 202, 50080 Zaragoza, Spain
}

Keywords:

chlorophyll fluorescence /

bark chlorenchyma /

frost damage

(Received 4 July 2008; accepted 10 September 2008)

Mots-clés :

fluorescence de chlorophylle / chlorenchyme de l'écorce corticale / dégâts du froid

\begin{abstract}
- Several techniques were used to investigate the threshold minimum temperature inducing severe frost damage during winter in Scots pine (Pinus sylvestris L.) needles and stems from southern provenances in the Iberian Peninsula.

- Chlorophyll (Chl) fluorescence, electrolyte leakage (EL), visual scoring (VS), and the normalized difference vegetation index (NDVI) were compared.

- Chl fluorescence, and in particular the maximum potential photosystem II (PSII) efficiency - estimated through the dark-acclimated $\mathrm{F}_{\mathrm{V}} / \mathrm{F}_{\mathrm{M}}$ ratio -, was found to be a simple, non-destructive indicator of freezing tolerance in needles, as expected.

- Moreover, the existence of a Chl-containing tissue, the cortical bark chlorenchyma, allowed us the use of Chl fluorescence as a new non-destructive indicator of frost damage in live tissues of Pinus sylvestris L. stems.

- Freezing tolerance values of southern provenances are compared with those found by other authors in the northern distribution limit of the species.
\end{abstract}

Résumé - Évaluation des dégâts du froid dans les troncs de Pinus sylvestris L. par la mesure de la fluorescence de la chlorophylle dans le chlorenchyme cortical de l'écorce.

- Plusieurs techniques ont été utilisées pour rechercher les seuils minima de température qui occasionnent des dommages dans les aiguilles et les troncs de pin sylvestre (Pinus sylvestris L.) de provenances méridionales de la péninsule Ibérique.

- Les résultats obtenus à partir de la mesure de la fluorescence de chlorophylle (Chl), de la libération d'électrolytes (EL), d'une évaluation visuelle (VS) et d'un indice d'activité végétale normalisé (NDVI) ont été comparés.

- La fluorescence de chlorophylle, et en particulier l'efficience maximale du photosystème II (PSII) qui est estimée à partir du rapport $\mathrm{F}_{\mathrm{V}} / \mathrm{F}_{\mathrm{M}}$ des échantillons acclimatés à l'obscurité, a été confirmée comme une méthode simple et non destructive pour estimer la tolérance au froid des aiguilles de pin, comme cela avait déjà mis en évidence par d'autres études.

- En outre, l'existence d'un tissu chlorophyllien dans la partie corticale de l'écorce du tronc a permis l'emploi avec succès de la mesure fluorescence de chlorophylle comme nouvel indicateur non destructif de la résistance au froid des tissus vivants des troncs de Pinus sylvestris L.

- Ces estimations de tolérance au froid, trouvées pour des provenances méridionales de Pinus sylvestris L., ont été comparées avec celles rapportées par d'autres auteurs pour des provenances plus septentrionales.

\section{INTRODUCTION}

Frost-induced damage is a major limiting factor that explains plant species distribution (Corcuera et al., 2005) due to the great amount of world's landmass that is subjected to subfreezing temperatures (Beck et al., 2004). To cope with

*Corresponding author: egilp@ aragon.es freezing damage, plant species have to withstand low temperatures without cell freezing and consequent cell dehydration stress (Repo et al., 2006). In pine species, the ultimate consequences for plant survival depend on the affected tissue. While an unpredictable needle shedding may not have any consequence on pine survival (Glynn and Lindelöw, 2002), the damage in the living tissues of the shoot inner bark will have 
fatal consequences for the whole-tree survival. Therefore, the further bud-burst will be severely affected (Court-Picon et al., 2004) in species without epicormic resprouting below the affected zones (Del Tredici, 2001). For these reasons, several authors have placed a primary emphasis on elucidating the degree of resistance of the inner bark under frost temperatures in conifer species (Jonsson et al., 2004, Luoranen et al., 2004).

Several techniques have been used to establish the threshold temperature for irreversible frost damage in the inner bark. Some of them have been widely used in various plant tissues, namely visual scoring (VS) (Luoranen et al., 2004), electrolyte leakage (EL) (Lu et al., 2007; Luoranen et al., 2004) and differential thermal analysis (Hacker and Neuner, 2007). Some alternative techniques have been specifically designed to quantify frost-induced damages and frost hardiness in living tissues of the stem, namely electrical impedance analysis (Repo et al., 2000a; 2000b), time domain reflectometry probe (Sparks et al., 2001) and measurement of visible-near infrared spectra (Sundblad et al., 2001). However, most of these techniques have some disadvantages, such as an excessive time comsumption, the subjectivity in the detection of visual changes or the need for a complex equipment. Therefore, according to Repo et al. (2000b), an easy and fast method for the determination of freezing tolerance, which allows a widespread use in forest ecology or breeding programmes, is still lacking.

Chlorophyll (Chl) fluorescence parameters, specially the maximum potential photosystem II (PSII) efficiency (estimated through the dark-acclimated $\mathrm{F}_{\mathrm{V}} / \mathrm{F}_{\mathrm{M}}$ ratio), have been widely used as indicators of frost stress in several Chlcontaining tissues (Bigras and Bertrand, 2006; Binder and Fielder, 1996; Perks et al., 2004; Westin et al., 1995). This technique allows researchers to quantify the level of frost stress in a great number of samples. Several authors have shown the existence of photosynthetic activity in the cortical bark chlorenchyma of stems in a wide variety of woody plants, including pine species (Ivanov et al., 2006; Wittmann and Pfanz, 2007; Wittmann et al., 2006). For this reason, changes in chlorophyll fluorescence due to frost damage could be used in the study of this tissue.

Therefore, the main objective of this work was to assess the usefulness of Chl fluorescence in these Chl-containing tissue (the cortical bark chlorenchyma) as a tool for the study of its freezing tolerance. Moreover, to test the reliability of this technique, EL and VS were used as reference techniques of the damages suffered by the whole tissue. For this purpose, we studied the freezing tolerance in needles and stems from a Scots pine (Pinus sylvestris L.) population located near its southern distribution limit $\left(40^{\circ} 30^{\prime} \mathrm{N}, 0^{\circ} 36^{\prime} \mathrm{E}, 1650 \mathrm{~m}\right.$ a.s.l., Teruel, Spain), which has not been previously studied, as compared to the northern ones (Repo et al., 2000a).

\section{MATERIALS AND METHODS}

\subsection{Plant material and study site}

A population of Scots pine located in the southern "Sistema Ibérico" range $\left(40^{\circ} 30^{\prime} \mathrm{N}, 0^{\circ} 36^{\prime} \mathrm{E}, 1650 \mathrm{~m}\right.$ a.s.1., Teruel, Spain) was selected for freezing exposure. In this study, we used currentyear needles, as a well-known reference organ in the response of PSII to frost damage, and five-year-old branches sampled from the middle part of the crown of 25 codominant healthy trees, randomly selected. Tree height and diameter at brest height $(\mathrm{DBH})$ averaged 6 and $0.25 \mathrm{~m}$, respectively. Immediately after samples were collected, they were stored in a black bag inside a thermoelectric refrigerator at $4{ }^{\circ} \mathrm{C}$ and carried to the laboratory. The study was carried out during January 2007, when freezing tolerance is expected to be maximum (Repo et al., 2000a).

Temperature was monitored in the forest in order to describe the thermal environment of the population of Scots pine studied (Fig. 1). Daily minimum, mean and maximum temperatures in the forest were characterized using four Hobo Pro RH/Temp data logger (Onset Computer Bourne, MA). The data logger was located within a solar shield in the lower canopy of a tree at $5 \mathrm{~m}$ above the soil. Measurements were recorded every 30 min during the period July 2006February 2007.

\subsection{Freezing exposure and freezing tolerance estimation}

Temperature profiles were made in the dark in a modified commercial freezer, establishing cooling rates through an industrial controller (PMA Prozess-und Maschinen-Automation GmbH Mod. KS90, Germany) acting on a heating block with forced convection. Freezing was provided by the continuous performance of the freezer engine. Thermal homogeneity was achieved through a microfan system arranged inside of the chamber (Esteso-Martínez and Gil-Pelegrín, 2004). This device provided a thermal stability of $\pm 0.1{ }^{\circ} \mathrm{C}$ on set temperature along the whole thermal profile. Samples (10 twigs and 10 shoots per test temperature) were exposed to various freezing temperatures between -2 and $-25{ }^{\circ} \mathrm{C}$. Shoot length and diameter averaged 0.15 and $0.015 \mathrm{~m}$, respectively. The rate of cooling was $5^{\circ} \mathrm{C} \mathrm{h}^{-1}$ and the exposition time to freezing temperature was $1 \mathrm{~h}$. This device was not able to drop the temperature below $-25^{\circ} \mathrm{C}$, so temperature profiles between -30 and $-80^{\circ} \mathrm{C}$ were made with a commercial freezer $\mathrm{CHF}$ 250/80 (Ing.Climas, Barcelona, Spain) equipped with a PID digital temperature controller, using the experimental procedure described above (the rate of cooling was $5{ }^{\circ} \mathrm{C} \mathrm{h}^{-1}$ and the exposition time to freezing temperature was $1 \mathrm{~h}$ ). The last device was not able to rise the temperature above $-30{ }^{\circ} \mathrm{C}$, so we had to use two different devices in this study. In all tests, the control temperature was $4{ }^{\circ} \mathrm{C}$.

The freezing tolerance of needles and stems was assessed by means of four methods: Chl fluorescence measurements, EL, NDVI and VS of damage according to needle and stem browning. The freezing tolerance was estimated as the inflection point of the logistic sigmoid function (Eq. (1))

$$
y=\left[A /\left(1+\mathrm{e}^{B(C-x)}\right)\right]+D
$$

where $x$ and $y$ refer to the exposure temperature and the value of the variable used for the estimation of freezing tolerance, respectively, $A$ and $D$ define asymptotes of the function, and $B$ is the slope at the inflection point $C$ (Repo et al., 2000b).

\subsection{Chl fluorescence measurements}

After freezing, when samples reached room temperature, modulated Chl fluorescence parameters were measured on needles and 


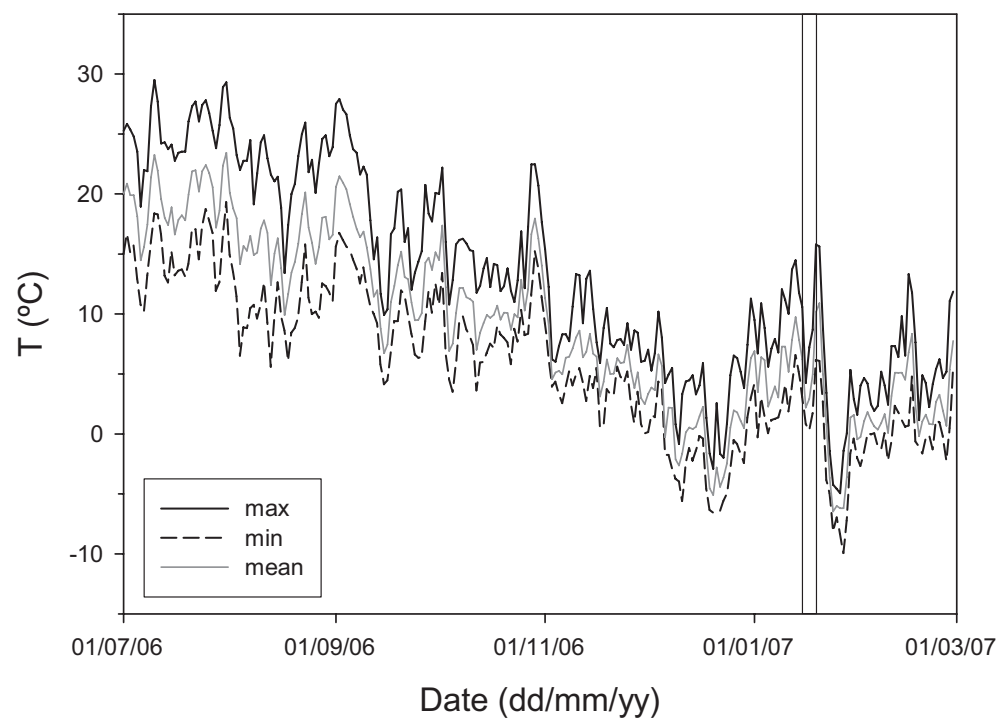

Figure 1. Minimum, maximum and mean temperature from July 2006 until February 2007 in the studied Scots pine population. Vertical lines indicate the sampling period (since 15 th to 19 th January 2007). cortical bark chlorenchyma with a FMS II portable pulse amplitude modulation fluorometer (Hansatech Instruments Ltd., Norfolk, UK). Plant tissues were covered with a black bag and kept in darkness for 30 min to estimate the minimum $\left(\mathrm{F}_{\mathrm{O}}\right)$ and maximum $\left(\mathrm{F}_{\mathrm{M}}\right)$ Chl fluorescence yield in the dark. $F_{O}$ was measured by switching on the modulated light; photosynthetic photon flux density (PPFD) was $0.4 \mu \mathrm{mol}$ $\mathrm{m}^{-2} \mathrm{~s}^{-1}$ at the leaf surface. $\mathrm{F}_{\mathrm{M}}$ was measured with a $0.8 \mathrm{~s}$ pulse of $9000 \mu \mathrm{mol} \mathrm{m} \mathrm{m}^{-2} \mathrm{~s}^{-1}$ of white light. The experimental protocol for the analysis of $F_{O}$ was essentially as described by Genty et al. (1989) with some modifications. These involved the presence of far-red light $\left(7 \mu \mathrm{mol} \mathrm{m} \mathrm{m}^{-2} \mathrm{~s}^{-1}\right)$ in $\mathrm{F}_{\mathrm{O}}$ measurements in order to fully oxidize the PSII acceptor side (Morales et al., 1998). The dark-acclimated, maximum potential PSII efficiency was calculated as $\mathrm{F}_{\mathrm{V}} / \mathrm{F}_{\mathrm{M}}$ (Morales et al., 1991), being $F_{V}=F_{M}-F_{O}$.

\subsection{Electrolyte leakage}

After freezing, two 1-cm-long pieces were cut and the bark removed from the lower and the upper parts of the branch (10 branches per test temperature) for testing EL, following the procedure described in Luoranen et al. (2004). In case of needles, one 1-cm-long sections were cut from the middle of each needle (16 needles per shoot and 10 shoots per test temperature) for testing EL. Samples (the bark that was removed from the branches and needles) were washed in distilled water, and each sample was put into a separate test tube containing $12 \mathrm{~mL}$ of distilled water. The tubes were incubated for $24 \mathrm{~h}$ at $4{ }^{\circ} \mathrm{C}$ to minimize microbial activity. The conductivity of the solution was measured at room temperature after the first incubation (Conductimeter Basic 30, Crison Instruments S.A., Spain). The tubes were incubated for $20 \mathrm{~min}$ at $96{ }^{\circ} \mathrm{C}$ to ensure the complete EL due to tissue injury. The second conductivity was measured after the samples reached room temperature. Relative EL was calculated as the ratio of the first and second conductivity measurements.

\subsection{Visual scoring}

After freezing, samples were wrapped in moistened blotter paper and placed in a growth chamber at temperatures of $20{ }^{\circ} \mathrm{C}$. Samples were sprayed daily with tap water. After 7 days, the damage was measured. We estimated the damage of each branch as the ratio of damaged, if the cambium and phloem were brown, to total surface of the branch. Needles were scored as damaged if they were brown or alive if they were green. Branch or needle damage was expressed as relative branch or needle browning and calculated as the ratio of total brown tissue to total sample (Luoranen et al., 2004).

\subsection{Spectral reflectance}

The accuracy of the VS can be improved by means of the measurement of reflectance changes in a spectral band near $700 \mathrm{~nm}$, as an easy and low-cost technique for the estimation of leaf Chl concentration (Carter and Knapp, 2001). We made spectral reflectance measurements in the inner bark to quantify VS in branches. We did not carry out spectral reflectance measurements in needles because they showed only two very sharply distinguised categories in the VS test (green/alive or brown/damaged). Therefore, it was considered that VS was accuracy enough to quantifiy visually the degree of frost damage in needles of Scots pine. Anyway, we made spectral reflectance measurements in 10 green/alive and 10 brown/damaged needles in order to quantify the differences in NDVI values from the two categories obtained in the VS test.

After measuring VS, spectral reflectance in the inner bark was measured between 306 and 1138 nm, using a UniSpec Spectral Analysis System (PP Systems, Herts, UK). We followed a similar procedure to that described by Richardson and Berlyn (2002). After spectral reflectance measurements were done, we calculated the NDVI, a spectral index strongly correlated with Chl content in green tissues (Richardson et al., 2002).

\section{RESULTS}

Figure 2 shows the evolution of $\mathrm{F}_{\mathrm{V}} / \mathrm{F}_{\mathrm{M}}$ in the cortical bark chlorenchyma and in the needles of Scots pine exposed to different frost temperatures during winter. According to this technique and following the logistic sigmoid regression model, 


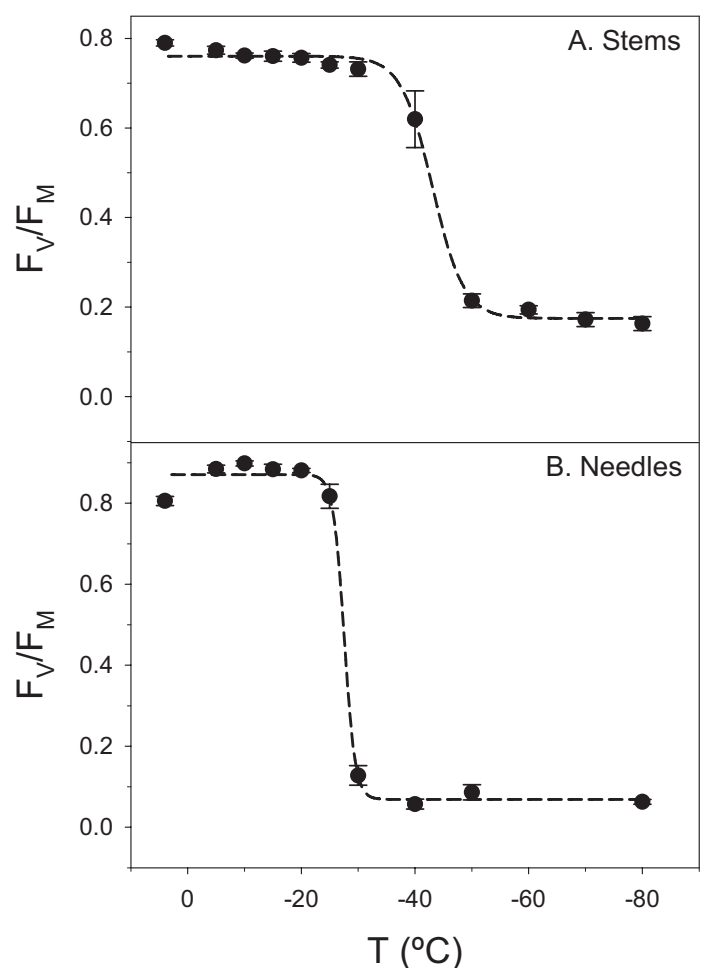

Figure 2. Relationships between temperature $\left({ }^{\circ} \mathrm{C}\right)$ and maximum potential PSII efficiency $\left(\mathrm{F}_{\mathrm{V}} / \mathrm{F}_{\mathrm{M}}\right)$ in $(\mathbf{A})$ stems and $(\mathbf{B})$ needles of Scots pine. Error bars indicate the standard error of the mean value.

Table I. Freezing tolerance values $\left({ }^{\circ} \mathrm{C}\right)$ for stems and needles of Scots pine during winter estimated from the different techniques used (see Material and methods section for details). Values are expressed as the estimated freezing tolerance \pm the standard error.

\begin{tabular}{lcc}
\hline \multirow{2}{*}{ Method } & \multicolumn{2}{c}{ Freezing tolerance $\left({ }^{\circ} \mathrm{C}\right)$} \\
\cline { 2 - 3 } & Stems & Needles \\
\hline $\mathrm{F}_{\mathrm{V} / \mathrm{F}_{\mathrm{M}}}$ & $-43.9 \pm 0.5$ & $-27.5 \pm 0.4$ \\
$\mathrm{EL}$ & $-45.8 \pm 0.6$ & $-25.5 \pm 0.3$ \\
$\mathrm{VS}$ & $-76.9 \pm 3.1$ & $-25.2 \pm 7.2$ \\
NDVI & $-43.8 \pm 7.4$ & - \\
\hline
\end{tabular}

freezing tolerance of the stems was $-43.9 \pm 0.5{ }^{\circ} \mathrm{C}\left(R^{2}=\right.$ $0.99, P<0.01)$, whereas freezing tolerance of the needles was $-27.5 \pm 0.4{ }^{\circ} \mathrm{C}\left(R^{2}=0.99, P<0.01\right)($ Tab. I).

The evolution of the EL in the stems and in the needles of Scots pine exposed to different frost temperatures during winter is shown in Figure 3. Following the logistic sigmoid regression model and using EL as measuring technique, freezing tolerance of the stems was $-45.8 \pm 0.6^{\circ} \mathrm{C}\left(R^{2}=0.89, P<0.01\right)$, whereas freezing tolerance of the needles was $-25.5 \pm 0.3{ }^{\circ} \mathrm{C}$ $\left(R^{2}=0.97, P<0.01\right)$ (Tab. I).

Figure 4 shows the evolution of the VS in the stems and in the needles of Scots pine exposed to different frost temperatures during winter. According to this technique and following the logistic sigmoid regression model, freezing tolerance of the stems was $-76.9 \pm 3.1{ }^{\circ} \mathrm{C}\left(R^{2}=0.99, P<0.01\right)($ Tab. I $)$. This value is different from the other estimates because these

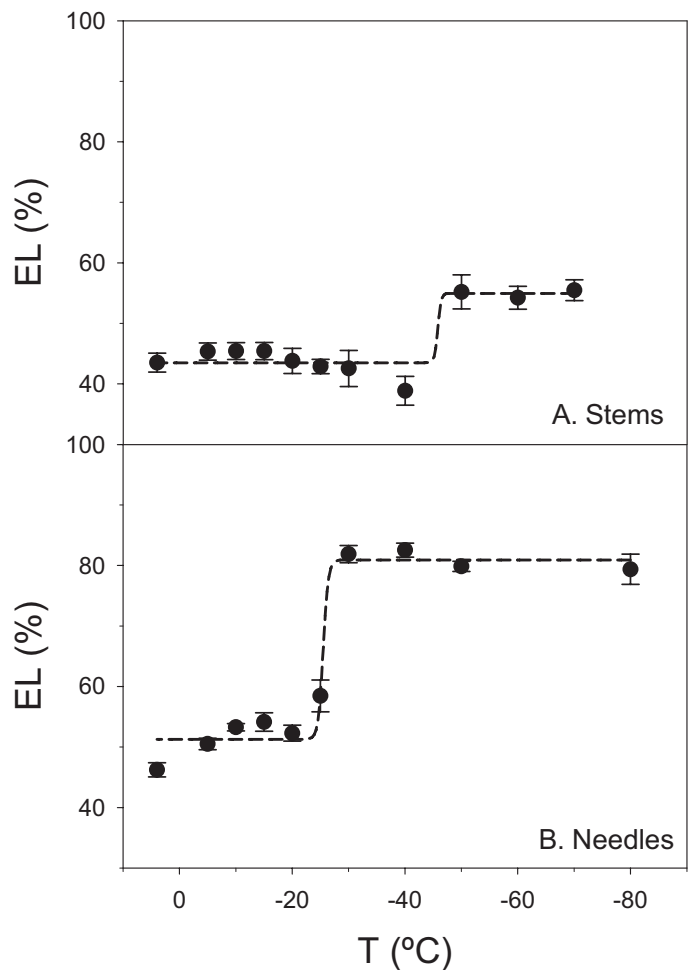

Figure 3. Relationships between temperature $\left({ }^{\circ} \mathrm{C}\right)$ and electrolyte leakage (\%) in (A) stems and (B) needles of Scots pine. Error bars indicate the standard error of the mean value.

data did not allow us to obtain an accurate logistic sigmoid regression model, according to the Equation (1) (Fig. 4). On the other hand, freezing tolerance of the needles was $-25.2 \pm$ $7.2{ }^{\circ} \mathrm{C}\left(R^{2}=0.99, P<0.01\right)($ Tab. I).

NDVI evolution of the stems of Scots pine exposed to different frost temperatures during winter is shown in Figure 5. According to NDVI data and following the logistic sigmoid regression model, freezing tolerance of the stems was $-43.8^{\circ} \mathrm{C}$ $\left(R^{2}=0.88, P<0.01\right)$ (Tab. I). On the other hand, NDVI from green/alive needles was $0.105 \pm 0.005$ and NDVI from brown/damaged needles was $0.073 \pm 0.004$ (data not shown).

\section{DISCUSSION}

In this work, we have compared several techniques aimed to study frost resistance in needles and stems of a Scots pine population located near its southern distribution limit. The estimated freezing tolerance values were very similar when results from different techniques could be compared (Tab. I), indicating that $\mathrm{Chl}$ fluorescence is an excellent non-destructive indicator of frost damage in needles and stems.

It should be noted that, although Chl fluorescence has been used for estimating freezing tolerance in needles (Binder and Fielder, 1996), the measurement of $F_{V} / F_{M}$ in cortical bark chlorenchyma for freezing tolerance estimation in stems has not been used yet. In this work we have reached $\mathrm{F}_{\mathrm{V}} / \mathrm{F}_{\mathrm{M}}$ values 


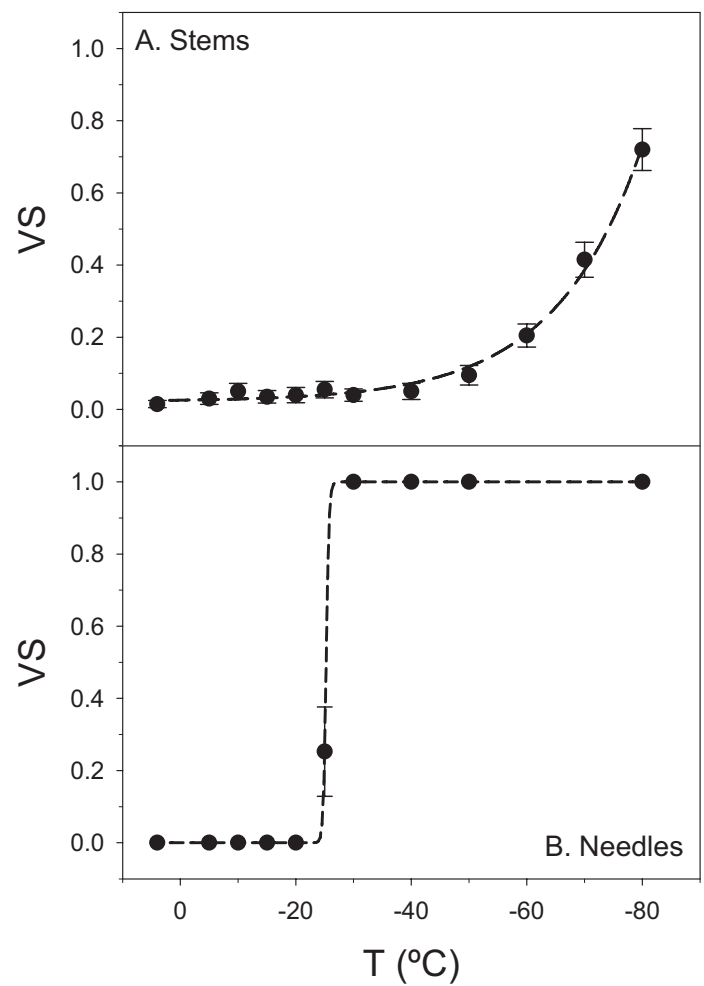

Figure 4. Relationships between temperature $\left({ }^{\circ} \mathrm{C}\right)$ and visual scoring (VS) in (A) stems and (B) needles of Scots pine. Error bars indicate the standard error of the mean value.

down to 0.15 in frost-damaged stems, indicating that these decreases were stronger than those due to winter photoinhibition without irreversible damage (Ivanov et al., 2006). This sharpen change in $\mathrm{F}_{\mathrm{V}} / \mathrm{F}_{\mathrm{M}}$ values gives an unambiguous criterium for the observer.

Regardless of technical aspects, results obtained indicated that the level of freezing tolerance in these Scots pine populations was always higher in stems than in needles, which indicates that cold acclimation varies according to organ and tissue type, as well as species, provenance and exposure temperature (Beck et al., 2004; Li et al., 2004). In this sense, the level of freezing tolerance found in needles of the studied Scots pine population during winter was much lower $\left(\mathrm{ca} .-26^{\circ} \mathrm{C}\right)$ than those reported by Taulavuori et al. (1997) and Repo et al. (2000a) (ca. $\left.-100{ }^{\circ} \mathrm{C}\right)$. The level of freezing tolerance found in stems during winter (ca. $-44^{\circ} \mathrm{C}$ ) was, however, close to that found by Repo et al. (2000a) (ca. $-46{ }^{\circ} \mathrm{C}$ ). The differential response in cold acclimation between needles and stems could be due to the great importance of cortical bark in the physiological performance of Scots pine. In the case of needle photosynthesis, the role of over-wintering needles as active photosynthetic tissues during the incoming years is severely limited in over-wintering conifers (Ivanov et al., 2006; Öquist and Huner, 2003). The main function of the bark chlorenchyma, however, seems to be the re-fixation of respiratory $\mathrm{CO}_{2}$, rather than the fixation of external $\mathrm{CO}_{2}$, maintaining a favorable carbon balance from late autumn to early spring (Ivanov et al.,

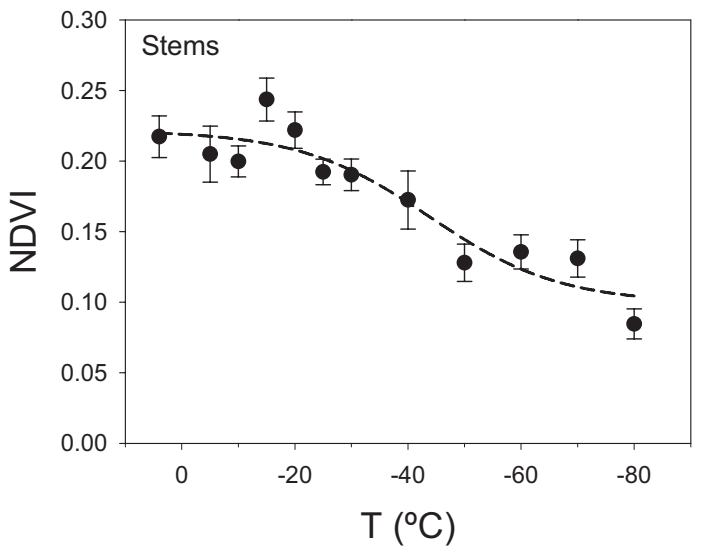

Figure 5. Relationship between temperature $\left({ }^{\circ} \mathrm{C}\right)$ and normalized difference vegetation index (NDVI) in stems of Scots pine. Error bars indicate the standard error of the mean value.

2006; Wittmann et al., 2006). Also, Ivanov et al. (2006) suggested that the preservation of photosynthetic activity of the cortical stem chloroplasts may have a significant impact on the recovery of the photosynthetic apparatus after the winter depression in pre-existing over-wintering needles.

In summary, Chl fluorescence of cortical bark chlorenchyma has been shown as an accurate, non-destructive, fast and easy technique for the characterization of cambium vitality in stems of Scots pine under frost temperatures. This technique allows to establish the threshold temperature in different plant tissues, including the inner bark, at which irreversible frost damage occurs.

Acknowledgements: This study was supported by a specific collaboration agreement between CITA-Aragón and Departamento de Medio Ambiente-Gobierno de Aragón.

\section{REFERENCES}

Beck E.H., Heim R., and Hansen J., 2004. Plant resistance to cold stress: mechanisms and environmental signals triggering frost hardening and dehardening. J. Biosci. 29: 449-459.

Bigras F.J. and Bertrand A., 2006. Responses of Picea mariana to elevated $\mathrm{CO}_{2}$ concentration during growth, cold hardening and dehardening: phenology, cold tolerance, photosynthesis and growth. Tree Physiol. 26: 875-888.

Binder W.D. and Fielder P., 1996. Chlorophyll fluorescence as an indicator of frost hardiness in white spruce seedlings from different latitudes. New For. 11: 233-253.

Carter G.A. and Knapp A.K., 2001. Leaf optical properties in higher plants: linking spectral characteristics to stress and chlorophyll concentration. Am. J. Bot. 88: 677-684.

Corcuera L., Morales F., Abadía A., and Gil-Pelegrín E., 2005. The effect of low temperatures on the photosynthetic apparatus of Quercus ilex subsp. ballota at its lower and upper altitudinal limits in the Iberian Peninsula and during a single freezing-thawing cycle. Trees 19: 99108.

Court-Picon M., Gadbin-Henry C., Guival F., and Roux M., 2004. Dendrometry and morphometry of Pinus pinea L. in Lower Provence (France): adaptability and variability of provenances. For. Ecol. Manage. 94: 319-333. 
Del Tredici P., 2001. Sprouting in temperate trees: a morphological and ecological review. Bot. Rev. 67: 121-140.

Esteso-Martínez J. and Gil-Pelegrín E., 2004. Frost resistance of seeds in Mediterranean oaks and the role of litter in the thermal protection of acorns. Ann. For. Sci. 61: 481-486.

Genty B., Briantais J.M., and Baker N.R., 1989. The relationship between the quantum yield of photosynthetic electron transport and quenching of chlorophyll fluorescence. Biochim. Biophys. Acta 990: 87-92.

Glynn C. and Lindelöw A., 2002. Defoliation by the needle-shortening pine gall midge Thecodiplosis brachyntera, on pines in central Sweden. Scand. J. For. Res. 17: 150-157.

Hacker J. and Neuner G., 2007. Ice propagation in plants visualized at the tissue level by infrared differential thermal analysis (IDTA). Tree Physiol. 27: 1661-1670.

Ivanov A.G., Krol M., Sveshnikov D., Malmberg G., Gardeström P, Hurry V., Öquist G., and Huner N.P.A., 2006. Characterization of the photosynthetic apparatus in cortical bark chlorenchyma of Scots pine. Planta 223: 1165-1177.

Jonsson A.M., Rosengren U., and Nihlgard B., 2004. Excess nitrogen affects the frost sensitivity of the inner bark of Norway spruce. Ann. For. Sci. 61: 293-298.

Li D., Junttila O., and Palva E.T., 2004. Environmental regulation and physiological basis of freezing tolerance in woody plants. Acta Physiol. Plant. 26: 213-222.

Lu P., Colombo S.J., and Sinclair R.W., 2007. Cold hardiness of interspecific hybrids between Pinus strobus and P. wallichiana measured by post-freezing needle electrolyte leakage. Tree Physiol. 27: 243-250.

Luoranen J., Repo T., and Lappi J., 2004. Assessment of the frost hardiness of shoots of silver birch (Betula pendula) seedlings with and without controlled exposure to freezing. Can. J. For. Res. 34: 11081118.

Morales F., Abadía A., and Abadía J., 1991. Chlorophyll fluorescence and photon yield of oxygen evolution in iron-deficient sugar beet (Beta vulgaris L.). Plant Physiol. 97: 886-893.

Morales F., Abadía A., and Abadía J., 1998. Photosynthesis, quenching of chlorophyll fluorescence and thermal energy dissipation in irondeficient sugar beet leaves. Aust. J. Plant Physiol. 25: 403-412.

Öquist G. and Huner N.P.A., 2003. Photosynthesis of overwintering evergreen plants. Annu. Rev. Plant Biol. 54: 329-355.
Perks M.P., Osborne B.A., and Mitchell D.T., 2004. Rapid predictions of cold tolerance in Douglas-fir seedlings using chlorophyll fluorescence after freezing. New For. 28: 49-62.

Repo T., Zhang G., Ryyppö A., Rikala R., and Vuorinen M., 2000a. The relation between growth cessation and frost hardening in Scots pine of different origins. Trees 14: 456-464.

Repo T., Zhang G., Ryyppö A., and Rikala R., 2000b. The electrical impedance spectroscopy of Scots pine (Pinus sylvestris L.) shoots in relation to cold acclimation. J. Exp. Bot. 51: 2095-2107.

Repo T., Leinonen I., Wang K.Y., and Hänninen H., 2006. Relation between photosynthetic capacity and cold hardiness in Scots pine. Physiol. Plant. 126: 224-231.

Richardson A.D. and Berlyn G.P., 2002. Spectral reflectance and photosynthetic properties of Betula papyrifera (Betulaceae) leaves along an elevational gradient on Mt. Mansfield, Vermont, USA. Am. J. Bot. 89: 88-94.

Richardson A.D., Duigan S.P., and Berlyn G.P., 2002. An evaluation of non-invasive methods to estimate foliar chlorophyll content. New Phytol. 153: 185-184.

Sparks J.P., Campbell G.S., and Black R.A., 2001. Water content, hydraulic conductivity, and ice formation in winter stems of Pinus contorta: a TDR case study. Oecologia 127: 468-475.

Sundblad L.G., Andersson M., Geladi P., Salomonson A., and Sjöström M., 2001. Fast, nondestructive of frost hardiness in conifer seedlings by VIS+NIR spectroscopy. Tree Physiol. 21: 751-757.

Taulavuori K., Niinimaa A., Laine K., Taulavuori E., and Lähdesmäki P., 1997. Modelling frost resistance of Scots pine seedlings using temperature, daylength and $\mathrm{pH}$ of cell effusate. Plant Ecol. 133: 181-189.

Westin J., Sundblad L.G., and Hällgren J.E., 1995. Seasonal variation in photochemical activity and hardiness in clones of Norway spruce, Picea abies L. Tree Physiol. 15: 685-689.

Wittmann C. and Pfanz H., 2007. Temperature dependency of bark photosynthesis in beech (Fagus sylvatica L.) and birch (Betula pendula Roth) trees. J. Exp. Bot. 58: 4293-4306.

Wittmann C., Pfanz H., Loreto F., Centritto M., Pietrini F., and Alessio G., 2006. Stem $\mathrm{CO}_{2}$ release under illumination: corticular photosynthesis, photorespiration or inhibition of mitochondrial respiration? Plant Cell Environ. 29: 1149-1158. 